\title{
Aristotle on Divine and Human CONTEMPLATION
}

\author{
BRYAN C. REECE \\ Harvard University, Center for Hellenic Studies \\ University of Chicago, Department of Philosophy
}

\begin{abstract}
Aristotle's theory of human happiness in the Nicomachean Ethics explicitly depends on the claim that contemplation (theôria) is peculiar to human beings, whether it is our function or only part of it. But there is a notorious problem: Aristotle says that divine beings also contemplate. Various solutions have been proposed, but each has difficulties. Drawing on an analysis of what divine contemplation involves according to Aristotle, I identify an assumption common to all of these proposals and argue for rejecting it. This allows a straightforward solution to the problem and there is evidence that Aristotle would have adopted it.
\end{abstract}

Keywords: Aristotle, intellect, nous, thinking, intentionality, imagination, soul, function argument, unmoved mover, celestial motion

\section{Is Contemplation Proper to Human Beings?}

In the Nicomachean Ethics Aristotle argues that we can infer the nature of human happiness by identifying some activity that is proper (idion, oikeion) to human beings. His celebrated 'function argument' in NE 1. 7 relies on such an inference, and there he rejects as candidates for happiness activities like self-nourishment, growth, and perception on the grounds that they are shared by beings other than humans. In NE 10. 7-8 he argues that human happiness is "a type of contemplation" ( $\theta \varepsilon \omega \mathrm{Q} i \alpha \tau \iota \varsigma)$ for the reason that the life characterized by contemplative activity is most proper to a human being. Aristotle is relying on the claim that only human beings are capable of contemplation. But many scholars have thought that his recognition that divine beings contemplate creates a problem. Their worry is expressed by the following argument:

ORCID: Bryan Reece ID 


\section{The argument from divine contemplation}

1. If contemplation is proper to human beings, then only human beings are capable of contemplation.

2. If divine beings are capable of contemplation, then it is false that only human beings are capable of contemplation.

3. Divine beings are capable of contemplation.

4. So, it is false that only human beings are capable of contemplation.

5. Therefore, contemplation is not proper to human beings.

If this conclusion holds, then Aristotle will be committed to saying that contemplation is and is not proper to human beings. Many commentators have addressed the argument from divine contemplation. ${ }^{1}$ Some accept (5) of the argument, attributing various degrees of inconsistency in thought or expression to Aristotle. Those who wish to reject (5) on his behalf have standardly denied premise (1). I will discuss these interpretations and their shortcomings in Section 2. In Section 3 I will survey the most relevant apparent evidence for premise (3), the texts that describe divine contemplation. Section 4 contends that the argument from divine contemplation is invalid because it equivocates on 'contemplation.' According to Aristotle, divine and human contemplation cannot be type-identical activities. ${ }^{2}$ This way of responding to the argument from divine contemplation closely parallels Aristotle's explicit response to a structurally similar argument dealing with animals, as Section 5 argues. There is, then, some reason to believe that he would have adopted the strategy that I elaborate if he had been confronted with the argument from divine contemplation. That argument thus gives us no reason to disbelieve Aristotle's claim that contemplation is proper to human beings.

1. Among those who have discussed this problem, but without arguing for the solution that I will advocate, are Ackrill (1997: 193), Aufderheide (2015: 54), Bush (2008: 65), Charles (2017a) and (2017b), Curzer (1990: 426-428), Curzer (2012: 411-412), Dahl (2011: 78), Joachim (1951: 50), Keyt (1983: 385), Kraut (1979) and (1989: 312-319), Lear (2004: 189-193), Nagel (1972: 255), and Whiting (1988: 37-38). Lawrence (2001: 445) mentions the problem but does not offer a solution. Wilkes (1978: 557-566) argues that Aristotle does not have a solution and his theory of happiness is therefore internally inconsistent.

2. This directly contradicts the assumption of several of the commentators mentioned above, as well as that of certain interpreters who discuss divine and human contemplation without explicitly addressing the problem with which I am concerned. These include Bodéüs (1992: 46), Bordt (2006: 116), Burnyeat (2008: 43), Lear (1988: 297-298), and Norman (1969: 67). Gauthier and Jolif (1970: 897) are not explicitly addressing the argument from divine contemplation or the problem that underlies it, though they say, as I do, that divine and human contemplation are type-distinct. See Footnote 20 and the section of the main text to which it refers for three differences between their comment and my proposal. 


\section{The Views of Other Commentators}

Three sets of responses have been offered to the argument from divine contemplation. The brief arguments that I offer against them, some of which have been given before, are not meant to show that they are unworkable, but rather to indicate that they are sufficiently controversial to motivate the solution to the problem that I will advocate in Section 4.

\subsection{Transhumanism}

Transhumanists accept the conclusion, (5). They think that contemplation is not proper to human beings as such, but only to the divine. ${ }^{3}$ There are multiple subspecies of transhumanist. For example, Ackrill (1997: 193), giving a slightly more detailed statement of the claim expressed by Joachim (1951: 50), thinks that since contemplation is not a good candidate for something that is proper to human beings, morally virtuous activities, which are more fitting candidates, must be the activities that Aristotle has in mind in the function argument of $N E$ 1. 7, and indeed in NE 1-9. He of course realizes that $N E$ 10. 7-8 upsets this picture, seemingly prioritizing contemplation. At the other extreme, Nagel (1972: 255) thinks that the argument from divine contemplation pushes us to admit that Aristotle has the apparently paradoxical view that the human good is not the human good, but rather the divine good. To live well as human beings, we must transcend living as human beings at all. Whereas Ackrill's view favors a reading of the function argument that makes NE 10. 7-8 a non sequitur, Nagel's prioritizes a reading of $N E$ 10. 7-8 that comes as a severe shock to readers of the function argument.

The problem with any version of transhumanism is that it forces us to think that contemplation, whether it is part, all, or one kind of human happiness, is not part, all, or one kind of it in virtue of being proper to a human being. But both the function argument and NE 10. 7-8 have standardly been taken to suggest that the human good ought to count as the human good in virtue of being proper to those beings whose good it is. ${ }^{4} \mathrm{~A}$ response to

3. Proponents of this view include Ackrill (1997: 193), Bush (2008: 65), Charles (2017a) and (2017b), Curzer (1990: 426-428), Joachim (1951: 50), Keyt (1983: 385), and Nagel (1972: 255).

4. Whiting (1986: 88-90) inveighs against a position that she calls "the transcendental account," the view that Aristotle is interested in the human good in the function argument, but in a good that transcends the human good in NE 10, on the grounds that such an account threatens the coherence of the $N E$ (particularly since, as she points out, $N E 10.5,1176^{\mathrm{a}} 3-4$ seems to refer to the function argument). Thorsrud (2015: 355-356) highlights this threat with reference to $N E$ 1. 6, 1096 $6^{\mathrm{b}} 31-35$, which suggests that the object of investigation in the $N E$ is a good that human beings are capable of achiev- 
the argument from divine contemplation that lacked this problem would be desirable. ${ }^{5}$

\subsection{Composite Essence}

Another view, advocated principally by Whiting (1988: 37-38) and adopted in various forms by Aufderheide (2015: 54), Curzer (2012: 411-412), Dahl (2011: 78), and Lear (2004: 189-193), is that contemplation considered in its own right is not proper to human beings, but considered as part of a composite set of activities it is proper to human beings. ${ }^{6}$ That is because, according to this view, the human essence is composite, including the capacities for intellectually and morally virtuous activities, and the human function is the manifestation of these essential capacities. So, it is true in a way that contemplation is proper to human beings since it is part of the human essence and that in turn is proper to human beings. But it is false that only human beings contemplate because divine beings contemplate, too. This composite essence view, then, denies premise (1) of the argument from divine contemplation and thus avoids the conclusion.

There are two problems for this view. The first is dialectical. Supposing that the human essence is composite in such a way as to include capacities for intellectually and morally virtuous activities commits one to a highly controversial metaphysics of human beings. ${ }^{7}$ It clashes with a standard way of reading $N E$

ing. Unlike Whiting, Thorsrud thinks that Aristotle's account does not escape the threat, and that is because Aristotle is genuinely pulled in two different directions and is honest about this.

5. Charles (2017a) and (2017b), which articulate a particularly nuanced version of transhumanism, would presumably contravene the common interpretation according to which the human good ought to count as the human good in virtue of being proper to those beings whose good it is. Charles thinks that what is proper to human beings is a whole pattern of life activities, considered as a whole, and that only some of these activities, including contemplation, are part of the human function. Contemplation, considered as an activity in its own right, is not proper to human beings, according to Charles. Interpreters will disagree with Charles if they think that the answer to Aristotle's question, "What, then, would this characteristic activity (ergon) [of a human being] be?" (NE 1. 7, 1097 33 ), is constrained by his claim in the next line that "we seek what is proper (idion) [to a human being]" ( $\left.1097^{\mathrm{b}} 34\right)$, and is given first in general form as "a kind of active life of the part that has reason" (1098 $\left.8^{\mathrm{a}}-4\right)$ and then more specifically as "activity of the soul in accordance with virtue, and if there are multiple virtues, then in accordance with the best and most complete/final/ perfect" $\left(1098^{\mathrm{a}}{ }_{16}-18\right)$. An interpreter who takes this to be Aristotle's pattern of reasoning will think that there is no room for Charles's distinction between the set of proper life activities of a human being described in this passage and the human function.

6. The idea that in the function argument Aristotle appeals to a composite set of activities that is proper to a human being, even though individual activities in that set might not be, echoes Irwin (1980: 49): "If $x$ can do A, B, and C, and nothing else can do C, but other things can do A and B, we might describe $x^{\prime}$ s peculiar function either as 'doing $A, B$, and $C^{\prime}$ or as 'doing C.' Now it is fairly clear that Aristotle understands the peculiar activity of man in the first, inclusive way."

7. I do not want to argue here that the very idea of a composite essence is problematic, but rather that a notion of composite essence that is of the appropriate shape to address the argument 
10. $7,1178^{\mathrm{a}_{2}-7}$ as claiming that human beings are theoretical intellect, as well as with interpretations of De anima, such as Cooper's (1975: 168-177), according to which theoretical and practical thought are separable from humans' other powers to different extents. This does not mean that the composite essence view is an unacceptable way of responding to the argument from divine contemplation, but a way of responding to that argument that does not rely centrally on a contentious metaphysics of human beings would be preferable. ${ }^{8}$

The other problem for the composite essence view is that even if it is plausible as an interpretation of the function argument, it struggles to account for the way in which Aristotle argues in NE 10. 7-8 that contemplation is proper to human beings. ${ }^{9}$ That is because he argues there that contemplation is most proper to human beings and morally virtuous activities are proper to them in a secondary way. But if, as the composite essence view has it, contemplation and morally virtuous activities are part of the human function because the capacities for these activities are all equally part of the human essence, then it is difficult to see what could ground the primary/secondary distinction. Each would be a manifestation of capacities that are part of the human essence, and thus proper to human beings in the same way. ${ }^{10} \mathrm{~A}$ response to the argument from divine contemplation

from divine contemplation, that is to say, one that entails that contemplation is proper to human beings only insofar as it is part of a package of activities that expresses the human essence, will require controversial interpretations of Aristotle's remarks about what psychic powers and activities are most proper to humans. Thanks to an anonymous reviewer for urging clarity on this point.

8. Bush (2008: 65 n. 23) thinks that there is a different dialectical problem. He complains that the composite essence view assumes inclusivism, the view that happiness essentially includes morally and intellectually virtuous activities, and should therefore be rejected if inclusivism should be. Since Lear (2004: 189-193) claims to follow Whiting's (1988: 37-38) composite essence view, but is not an inclusivist according to Bush or to me, either Bush is mistaken or the composite essence view is unavailable to Lear. Charles mentions in his (2017a: 107) and (2017b: 96) yet another dialectical problem for the composite essence view: that view gives no principled way of including contemplation in the composite essence without also including perception, although Aristotle excludes perception from our function (NE 1. 7, 1098 $\left.{ }^{\mathrm{a}} 1-3\right)$. A proponent of the composite essence view might respond that the human essence is restricted to the rational soul and excludes perceptual capacities for that reason, but Charles presumably regards such a response as unprincipled.

9. For a detailed analysis of Aristotle's argument in these chapters see Reece (2020).

10. An anonymous reviewer wonders whether this problem could be addressed by distinguishing two levels of analysis, such that at one level the capacities are all equally part of the human essence and at another, finer level a primary/secondary distinction is discernible. I worry that even if such a distinction in levels of analysis of a composite human essence could be derived from the function argument and $N E$ 10. 7-8, and if some suitable ground for the distinction that is compatible with the composite essence view could be specified, the argument from divine contemplation would reemerge at the finer level of analysis. If divine beings contemplate, it will be at least as problematic to say, at whatever level of analysis, that contemplation, rather than morally virtuous activity, is proper to humans in a primary way (as Aristotle says in NE 10. 7-8) as it is to say that contemplation, rather than morally virtuous activity, is proper to humans. In short, I worry that the composite essence proponent's ability to respond to the argument from divine contemplation depends on the impossibility of isolating contemplation in its own right as being proper (or proper 
that made good sense not only of the function argument but also of NE 10. $7-8$ would be preferable.

\subsection{Relativism}

A third view, advocated by Kraut (1979) and (1989: 312-319), urges a relativistic rendering of 'proper.' According to Kraut, whereas Aristotle sometimes uses 'proper' in what we might think of as the more standard, absolute sense according to which it restricts a property to items of a given kind, in the function argument and other parts of the NE he uses it to mean "proper to humans relative to all lower forms of life." That is to say, in the relevant contexts Aristotle means only to identify properties that humans have but animals and plants do not, regardless of whether divine beings have them, too. In this relativistic sense of 'proper,' it is true to say that contemplation is proper to human beings since lower forms of life cannot contemplate, but false that only humans contemplate since divine beings do so, too. Thus, like the compound essence view, the relativist view avoids the conclusion of the argument from divine contemplation by denying premise ( 1 ).

The problem with relativism is that it would be very difficult to divine such a meaning of 'proper' from the text of the $N E,^{11}$ and there would be little motivation to do so unless one had been confronted with the argument from divine contemplation. This view thus seems ad hoc and should therefore be an interpretation of last resort.

\section{Divine Contemplation}

Having discussed existing responses to the argument from divine contemplation, I will survey the most relevant apparent evidence for premise (3) of that argument. There are two main texts that might appear to suggest that human and divine contemplation are type-identical. In this section I will contend that these texts are inconclusive and are most conservatively interpreted as saying merely that human and divine contemplation are similar in certain respects that are important for Aristotle's arguments in each context. ${ }^{12}$ In the next section I

in a primary way) to humans at any level of analysis, but the possibility of such isolation is central to the most plausible interpretations of $N E$ 10. 7-8.

11. Curzer (1990: 427 n. 17) replies to Kraut as follows: "If Aristotle wanted the reader to take idion [proper] as relative to something, then he would have specified which something. Since he did not do so, we must take idion in an absolute sense."

12. This conclusion about the passages' status agrees with that of Herzberg (2013: ch. 4), though my analyses of the passages, particularly of the first, differ in detail from his. 
will argue that Aristotle cannot intend to describe human and divine contemplation as type-identical.

T1: NE 10. 8, $1178^{\mathrm{b}} 7-32^{13}$

1) It would appear from the following considerations, too, that perfect/com-

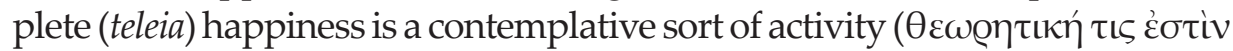

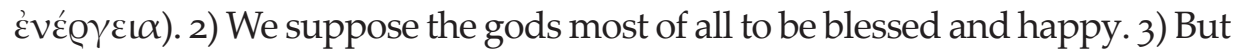
what kind of actions (praxeis) ought to be ascribed to them? 4) Actions that are just? 5) Or will they not appear ridiculous entering into contracts, returning deposits, and all such things? 6) Courageous actions, enduring fearful things and facing danger because doing so is noble? 7) Or generous actions? 8) To whom will they give? 9) It would be odd for them to have money or anything of that sort. 10) And what would their temperate actions be? 11) Or would not such praise be cheap since they do not have base appetites? 12) If we were to go through all of the things concerned with such actions it would appear that they are trivial and unworthy of gods (

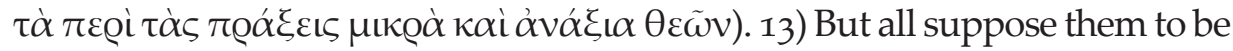
alive and therefore active, for surely they cannot suppose them to be sleeping like Endymion. 14) So then, if acting (prattein) (and still more, producing) is removed from living, what is left besides contemplation (theôria)? 15) The re-

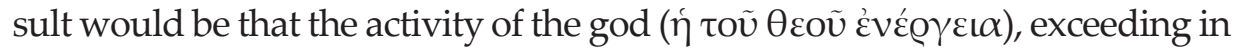
blessedness, is contemplative (theôrêtikê). 16) And indeed, among human activities the one that is most akin to this is the most characteristic of happiness

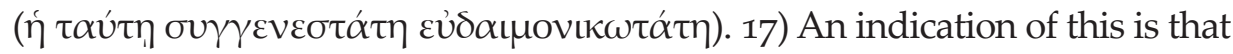
the other animals do not share in happiness, being completely deprived of this sort of activity. 18) For in the case of the gods the whole of life is blessed, whereas in the case of human beings this is so only so far as there is some

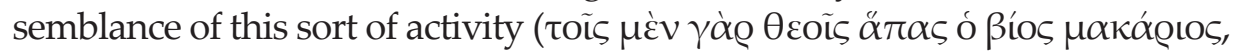

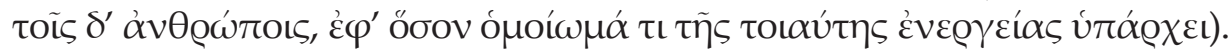
19) But among the other animals none is happy since none shares in contem-

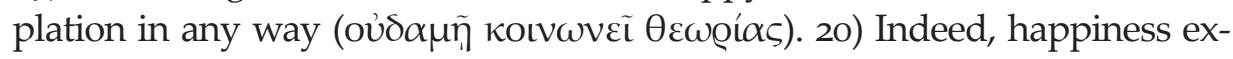
tends as far as contemplation does, and to those to whom it more belongs to contemplate, it more belongs also to be happy, not accidentally, but rather in

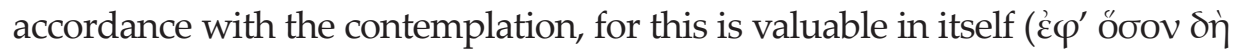

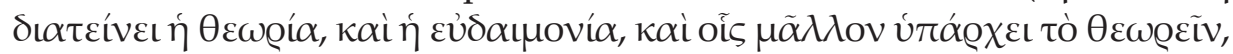

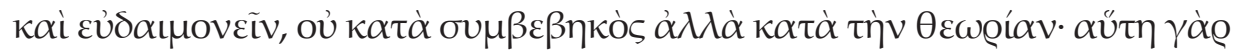
$\left.\kappa \alpha \theta^{\prime} \alpha \dot{v} \tau \eta \dot{v} v \tau \mu i^{\prime} \alpha\right)$. 21) The result would be that happiness is a type of con-

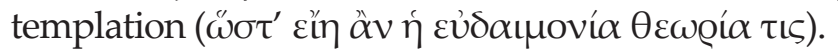

13. Translations are mine.

Ergo •vol. 7, no. $4 \cdot 2020$ 
According to what I shall call an 'identity reading,' T1 commits Aristotle to the claim that human and divine contemplation are type-identical. On a 'similarity reading,' it commits him only to the claim that they are similar. If one has an identity reading, one might suppose that Aristotle argues roughly as follows, deducing the general nature of happiness from the nature of divine happiness as contemplation:

i) The gods are happy, alive, and active, but they do not engage in morally virtuous activities.

ii) If the gods are happy, alive, and active, but do not engage in morally virtuous activities, then the only activity remaining for them would be contemplation.

iii) So, the only activity for gods is contemplation.

iv) If happiness is an activity, it is that of contemplation.

v) Happiness is an activity.

vi) Therefore, happiness is contemplation.

The idea that human and divine contemplation are type-identical is supposed to gain support from Aristotle's argument thus interpreted. However, there is a problem: Either happiness for gods and happiness for humans are typeidentical or they are not. If they are not, then the passage licenses no inference to the claim that divine and human contemplation are type-identical. We would have to assume that gratuitously. If happiness for gods and happiness for humans are type-identical, however, it would be completely superfluous to mention that animals do not share in happiness or contemplation. That is because Aristotle would need only the following argument to show that human happiness is contemplation: Divine happiness is contemplation. If divine happiness and human happiness are type-identical, then human happiness is contemplation. Divine happiness and human happiness are type-identical. Therefore, human happiness is contemplation.

It remains possible that this is Aristotle's argument in the passage, with the result that he is committed to human and divine contemplation being typeidentical. But attributing such a commitment to him should be an interpretation of last resort since, as we have seen already, Aristotle is elsewhere committed to contemplation being proper to human beings. Fortunately, 'similarity readings' of the passage are possible, and these do not commit Aristotle to the typeidentity of human and divine contemplation. One interpretation of his argument in this passage that would involve a similarity reading construes the argument as an appeal to the best explanation of various opinions of others: People say that all gods are happy, some humans are, and no animals are. But gods engage in no morally virtuous activities, which we might have been tempted to identify 
with happiness. The best explanation for these claims is that-and now we move to Aristotle's official view rather than the imprecise terms of the opinions ${ }^{14}-$ all gods are happy in a way peculiar to them because they all engage in a sort of contemplation peculiar to them, some humans are happy in a way peculiar to them because they engage in a sort of contemplation peculiar to them but similar to that in which the gods engage, and no animal is happy since no animal engages in any sort of contemplation. If this is right, Aristotle can then make both the extensional claim and the causal claim that, for human beings, happiness extends just as far as (human) contemplation does and the happiness is because of the contemplation. This makes human happiness similar to the happiness of the gods. The nexus of similarity is that both kinds of happiness are what they are because of the contemplation. The happiness of the gods is what it is because of divine contemplation, and the happiness of humans is what it is because of human contemplation. Contemplation of whatever sort plays a similar role in happiness of whatever sort. In this way of interpreting the argument of $\mathrm{T}_{1},(20)$ and (21) apply only to human happiness, and no premise in the argument asserts the type-identity of human and divine contemplation. Rather, Aristotle means to say only that human contemplation is "most akin" to divine contemplation (16) and that happy humans must engage in "some semblance of this sort of activity" (18), namely, some semblance of divine contemplation. It is preferable to adopt an interpretation of $\mathrm{T}_{1}$ that has these features if at all possible since Aristotle elsewhere is committed to the claim that contemplation is proper to human beings. ${ }^{15}$

T2: Metaph. 12. $7,1072^{b_{13}-30}$

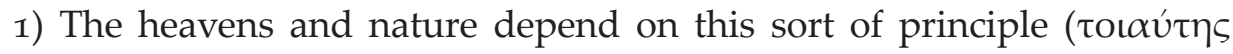
$\dot{\alpha} \mathrm{\chi} \tilde{\eta} \varsigma) .2$ ) And this principle's occupation (diagôgê) is like the best that we for a short time engage in. 3) For it is always thus occupied (whereas we cannot be), since its activity is also pleasure (and because of this wakeful-

14. Bodéüs (1992: 239) thinks that this passage is Aristotle's only exposition of theology. This is surprising. What is not surprising is that Bodéüs also thinks that this passage says that divine and human contemplation are type-identical (1992: 46). Gauthier and Jolif (1970: 897) have a sharply contrasting view: Aristotle's remarks in this passage about the gods are "ad hominem."

15. I take it that if one adopts a similarity reading of $\mathrm{T}_{1}$, one can do so also for $N E$ 10. 7, $1177^{\mathrm{b}} 31-34$ and 10. 8, 1179 ${ }^{\mathrm{a}} 22-32$. The first of these enjoins us as humans to "immortalize ourselves to the extent possible for us" and the second leverages the popular opinions that there are providential gods who most love those humans who contemplate-Aristotle does not believe that these opinions are literally true, as I will discuss in Section 4, though Bodéüs (1992) disagreesto argue that contemplation is the noblest activity and the one most characteristic of happiness. Neither passage suggests type-identity (rather than mere similarity) between human and divine contemplation. 
ness, perception, and thinking (noêsis) are most pleasant, whereas hopes and memories are so with reference to these). 4) Thinking (noêsis) in its own right is of what is best in its own right, and what is most of all think-

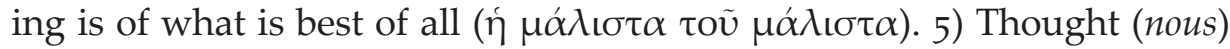

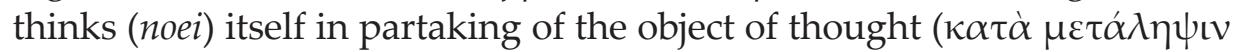

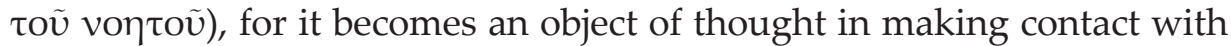

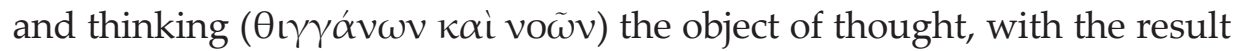
that thought (nous) and the object of thought (noêton) are the same (tauton). 6) For thought (nous) is what is capable of receiving the object of thought, viz., the essence/substance ( oú $\sigma i \alpha \varsigma)$, and it is active when it has it, with the result that the latter more

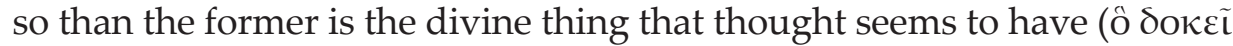

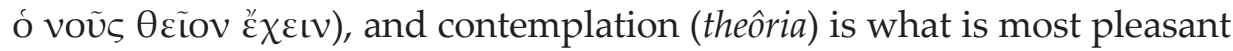
and best. 7) If, therefore, the god (ó $\theta \varepsilon \dot{s} \varsigma$ ) is always doing well in the way

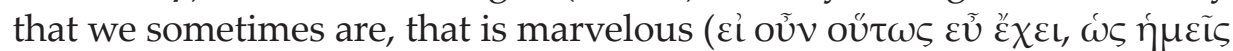

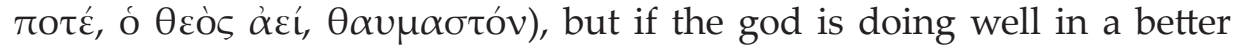

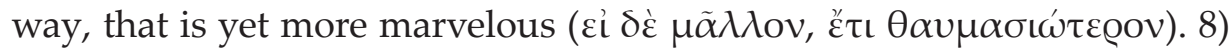
The latter is the case. 9) Life also belongs to the god, for thought's (nous) activity is life, and the god is that activity. 10) The god's activity in its own right is life that is best and eternal. 11) We say, then, that the god is a living being, eternal, and best, with the result that life and continuous and eternal duration belong to the god, for this is the god.

The motivation for an identity reading of T2 comes mostly from sentence (2). On such a reading, Aristotle's point in this passage would be that human and divine contemplation are the same in type and differ only with respect to continuity and duration: human contemplation is intermittent and of finite duration, whereas divine contemplation is continuous and of eternal duration. Sentence (2) considered in its own right is ambiguous between an identity reading and a similarity reading, so it could mean this. However, sentences (7)-(8), at least on one plausible interpretation, disambiguate (2) in favor of the similarity reading. ${ }^{16}$ The god's activity is of a type that is better than, and therefore distinct from, the human activity. Sentence (4) opens up the possibility that the distinction might have something to do with differences in object of thought. ${ }^{17}$ The god's thinking is always and necessarily directed at the highest object, whereas our thinking is apt to be diverted in a variety of ways. Even sentence (3) can be interpreted as foreshadowing the claim in (7)-(8) that human and divine contemplation are merely similar. It depends on what Aristotle means in (3) by "we cannot be." He

16. This is also argued by Herzberg (2013: 147) and (2016: 164, 174-175), as well as by Laks (2000: 233).

17. Laks (2000: 234) suggests something similar. 
could mean that we cannot be perpetually engaged in the same activity as the god is, or that we cannot be engaged in the same activity at all. The identity reading requires the first of these two options. The reasons why human and divine contemplation are distinct in type will be clearer when we come to Aristotle's more substantive description of divine contemplation in Metaph. 12. 9. For now it is enough to note that there is a way of reading $\mathrm{T}_{2}$ that has this result.

On the similarity reading of $\mathrm{T} 2$, how are human and divine contemplation similar? At the very least, both have an intelligible object (sentences (5)-(6)) and are, or are associated with, the highest pleasure that each sort of being can experience and are the best activities in which each can engage, as Aristotle argues in sentences (3), (4), and (6). Further respects in which they are similar or different are difficult to describe precisely on any interpretation of $\mathrm{T} 2$.

We have seen that $\mathrm{T}_{1}$ and $\mathrm{T}_{2}$ can both be interpreted as saying that human and divine contemplation are similar in certain respects (being that which principally constitutes the happiness of each, having an intelligible object, and being or being associated with the highest pleasure that each can experience) rather than that they are type-identical. In the next section I will argue that Aristotle cannot consistently think that they are type-identical.

\section{Why Divine and Human Contemplation Cannot Be Type- Identical Activities}

In this section I will contend that the argument from divine contemplation, which I presented in Section 1, is invalid because it equivocates on 'contemplation.' There are two type-distinct kinds of contemplation at issue in the argument, one human and one divine. Furthermore, as I will argue in Section 5, there is evidence that Aristotle would prefer this way of responding to the argument from divine contemplation if he had been presented with it. Parts of my argument that divine and human contemplation are different in type have been given, at least in cursory form, in literature on Metaphysics and De anima. ${ }^{18}$ However, this literature does not argue, as I will, on the basis of a consideration internal to Aristotle's ethical theory, the context in which type-identity would generate the problem with which I began. My argument is that human and divine contemplation must be distinct in type because only the former is a manifestation of

18. The following either state that, according to Aristotle, human and divine contemplation are distinct in type or give arguments on the basis of which this can be concluded: Aquinas (1950: 2613-2615), Averroes (1984: 1700-1708), Beere (2010: 27-30), Brunschwig (2000: 296-301), Cohoe (2014: 599), Cohoe (in press), Gerson (1990: 127 and 284 n. 87), Herzberg (2013: ch. 4) and (2016), Kosman (2000: 311), Menn (2012: 446-447), Modrak (1991: 770), Ross (1953: 379), Segev (2017: 109), Silverman (2010: 92-93), and Wedin (1988: 229-245). 
theoretical wisdom (sophia) as Aristotle describes it in his ethical works. This distinctive way of arguing permits an otherwise unavailable response to a powerful objection that I will discuss in Section 5. Furthermore, the arguments in the existing literature tend to focus on the differences between the unmoved mover and human beings, leaving largely unexplored whether divine beings other than the unmoved mover might contemplate in the way that we can. ${ }^{19} \mathrm{Fi}$ nally, the existing considerations have not been directed toward addressing the argument from divine contemplation. ${ }^{20}$ Indeed, there has not been much interaction between the literature that addresses that argument and the literature that discusses in detail the nature of divine contemplation. This is unfortunate since, as will emerge in what follows, consideration of both issues together promotes a more accurate understanding of each.

\subsection{How to Distinguish Types of Activities}

Not every difference between two activities is a difference in type. There are significant differences between, for example, plant nutrition and human nutrition, as well as between animal perception and human perception. Plant nutrition involves roots, human nutrition mouths. Lizard vision is mediated by hard eyes, human vision by soft. Humans smell by inhaling through the nose, whereas bloodless animals do not. But Aristotle thinks that such differences are not in type (DA 2. 9, $\left.421^{\mathrm{b}} 13^{-}-422^{\mathrm{a}} 7\right)$. Even when the activity of smelling takes place through different organs, the per se object of smelling is always the same: odor. Whereas a difference in per se objects suffices for a difference in type of activity, a difference in the material substratum (e.g., organ) affected per se by the same objects does not.

This would follow from an extension of the general account of how to determine whether two things are distinct in species that Aristotle articulates in Metaph. 10. 8-9. ${ }^{21}$ On that account, $x$ and $y$ are distinct in species if $F$ belongs to $x$ in virtue of $x$ 's form, $G$ belongs to $y$ in virtue of $y$ 's form, and $F$ and $G$ are contraries. $x$ and $y$ are not distinct in species if $F$ belongs to $x$ in virtue of $x^{\prime}$ s matter and $G$

19. Cohoe (in press) and Segev (2017: ch. 3) are partial exceptions. Cohoe focuses not on whether divine beings other than the unmoved mover contemplate in the way that we can, but rather on demonstrating that such beings are alive but lack souls. His argument has implications for certain issues that I discuss, such as whether celestial bodies have phantasia. Segev more directly discusses the relationship between the cognitive activities of humans and of divine beings, but is more hospitable than I am to the conclusion that these activities possess "essential commonality" (2017: 120).

20. Each of these three descriptions of remarks in existing literature applies to the comment by Gauthier and Jolif (1970: 897), which I have already mentioned as being broadly similar to the view that I adopt in denying that divine and human contemplation are type-identical.

21. I take distinctness in species to be sufficient for distinctness in type. 
belongs to $y$ in virtue of $y$ 's matter, regardless of whether $F$ and $G$ are contraries. For example, a brazen triangle and brazen circle differ in species, as do a brazen triangle and a wooden circle, but a brazen circle and a wooden circle do not. In short, contrariety due to form, which I shall call 'formal difference,' is sufficient for difference in species, but contrariety due to matter, which I shall call 'material difference,' is not. The Metaph. 10. 8-9 account of difference in species does not deal directly with activities. That is because activities, as non-substances, do not have matter strictly speaking (Metaph. 8. $4,1044^{\mathrm{a}} 32^{-}{ }^{\mathrm{b}} 20$ ), and therefore no difference due to matter strictly speaking. But they do have material substrata in virtue of which they can differ. If differences due to matter include differences due to the material substrata of two activities, then the Metaph. 10. 8-9 account of difference in species can be extended to cover activities. If Aristotle is indeed extending that account in this way, it would explain why he indicates in De anima that a difference in per se objects suffices for a difference in type of activity, but a difference in the material substratum affected per se by the same objects does not.

In addition to, or perhaps as evidence of, having different per se objects (or more generally, being concerned with different things), activities can exhibit one or more of the following indicators of difference in type. They can differ in that one of them, but not the other, is up to us to perform by choice $\left(D A 3 \cdot 3,427^{\mathrm{b}} 16-\right.$ $20)$, constantly performed $\left(428^{\mathrm{a}} 8-9\right)$, or fallible $\left(428^{\mathrm{a}} 11-12 ; N E 6.3,1139^{\mathrm{b}} 14-18\right)$, or one implies another activity or state that the other does not $\left(D A 3 \cdot 9,432^{\mathrm{b}} 14-\right.$ 26), or they are concerned with things that have a different modal status ( $N E 3$. $\left.2,1111^{\mathrm{b}} 19-23 ; 6.3,1139^{\mathrm{b}} 19-24\right)$. Furthermore, Aristotle thinks that if activity $x$ is concerned with more kinds of things than activity $y$ is, $x$ and $y$ are type-distinct. For example, whereas epistêmê (the developed capacity for scientific demonstration from first principles) and theoretical wisdom are concerned with universals, practical wisdom is concerned not only with universals, but also with particulars, and is therefore type-distinct from the others (NE 6. $7,1141^{\left.b_{2}-15\right) .}{ }^{22}$ Such differences are formal rather than material (adverting to the extension of the Metaph. 10. 8-9 account mentioned previously) since they do not apply in virtue of the material substrata of the activities in question, but rather in virtue of the things with which they are concerned or the way in which they are concerned with them. ${ }^{23}$ Formal differences between activities, but not material differences, will be markers of type-distinctness. In the sections that follow I will argue that divine and human contemplation exhibit various formal differences and therefore are type-distinct.

22. This need not mean that practical wisdom is concerned with the same universals as epistêmê and theoretical wisdom are, but only that it differs from those because it is concerned not only with some universals or other, but also with particulars. That is to say, practical wisdom is concerned with more kinds of things.

23. For a detailed account of formal differences between, and material substrata of, activities, see Reece (2019). 
We know that these differences must be formal rather than material for the following reason: The unmoved mover's contemplation has no material substratum. On some interpretations of De anima, human contemplation does not. If it does not, then any difference between the unmoved mover's contemplation and human contemplation would have to be formal rather than material. If human contemplation does have a material substratum, then it would still differ in type from the unmoved mover's contemplation since the essence of one would be matter-involving and the essence of the other would not be. I will assume that if the unmoved mover's contemplation and human contemplation differ formally in respects $F, G, H$, etc., then differences in respects $F, G$, or $H$ between human contemplation and contemplation performed by divine beings other than the unmoved mover (such as celestial bodies) are also formal differences, whether or not the other divine beings and humans contemplate in a matter-involving way.

\subsection{Human Contemplation}

Aristotle thinks that any instance of human contemplation is a manifestation of the virtue of theoretical wisdom (sophia) in his technical sense (NE 10. 7, $\left.1177^{\mathrm{a}}{ }_{12-}{ }^{\mathrm{b}} 26,10.8,1179^{\mathrm{a}} 29-32\right),{ }^{24}$ which in turn includes two virtues: a particular sort of nous, the developed capacity to grasp first principles intuitively as first principles, and epistêmê, the developed capacity for scientific demonstration from first principles (NE 6. 7, 1141 $\left.{ }^{\mathrm{a}} 18-20,6.3,1139^{\mathrm{b}} 31-32\right)$. If divine beings lacked either of these capacities, then they would lack theoretical wisdom in Aristotle's technical sense. But then their contemplation could not be of the same type as human contemplation is since it would not be a manifestation of the same capacity. So, our question is: Do the divine beings that Aristotle recognizes have the aforementioned capacities, namely the developed capacity to grasp first principles intuitively as first principles and the developed capacity for scientific demonstration from first principles?

\subsection{The Range of Divine Beings}

In order to answer the question with appropriate generality, we need to identify what divine beings Aristotle recognizes. Most obviously, there is the first un-

24. Some advocate a more liberal view of what contemplation involves, according to which it can in some cases be fully virtuous inquiry, including Guthrie (1981: 396-398), Roochnik (2009), and Walker (2017). Such a view, or the proposal that contemplation can in some cases be a manifestation of practical wisdom, would make my argument in this section easier. That is because Aristotle's divine beings clearly do not engage in inquiry or possess practical wisdom (see TI above). I address the harder case of whether or not they have theoretical wisdom and manifest it in a comprehensive grasp rather than an inquiry, and so I assume the more conservative view of what contemplation involves. 
moved mover of Metaph. 12. ${ }^{25}$ This being is supposed to be responsible for the fact that there is continuous motion in the universe. Disputed questions about the range of beings moved by the unmoved mover, and whether the unmoved mover moves them as both a final cause and an efficient cause, are irrelevant for my purposes here. What is relevant is that Aristotle describes the unmoved

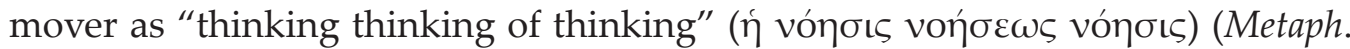
12. 9, $\left.1074^{\mathrm{b}} 34-35\right)$. The other divine beings in Aristotle's system are various celestial objects, including the rotating spheres that move other celestial objects, the stars, the planets, the sun, and the moon. Aristotle is clear that these are divine (Phys. 2. 4, 196 $6^{\mathrm{a}} 33_{-34}$, DC 2. 12, $292^{\mathrm{b}} 31-32$, PA 1. 5, 644 $24-25$, Metaph. 12. $\left.8,1074^{\mathrm{a}} 30-31, N E 6.7,1141^{\mathrm{a}} 34^{-{ }^{\mathrm{b}}} 2\right)$. Each of these celestial objects is perpetually engaged in unvarying, uninterrupted movement, which movement is supposed to be explained, either directly or derivatively, by the unmoved mover (or at least an unmoved mover) being a final cause for it in the way that an object of thought is (Metaph. 12. 7, 1072 $\left.{ }^{\mathrm{a}} 24-32\right)$. One might think that Aristotle's ontology includes, in addition to the unmoved mover and celestial objects, the gods of popular Greek religion. He does, after all, mention them frequently. However, this is no indication that he is committed to their existence; his mentions of them may reflect only popular opinions the appeal of which he wants his own theories of celestial objects to explain. ${ }^{26}$ This is what he seems to intend in such passages as $D C$ 1. 3, 270 ${ }^{\mathrm{b}} 1-24,1.9,279^{\mathrm{a}} 3 \mathrm{O}^{-\mathrm{b}^{\mathrm{b}}} 3,2.1,284^{\mathrm{a}} 2-14$, and Metaph. $12.8,1074^{\mathrm{b}} 1-14 .{ }^{27}$ Furthermore, those who take Aristotle to be committed to the type-identity of human and divine contemplation have a special reason to deny that he is committed to the existence of the gods of popular Greek religion. Recall the identity reading of the argument of $\mathrm{T}_{1}$ in Section 3. On that interpretation of Aristotle's argument, contemplation would have to be the only activity in which the gods engage. This means that the deities of popular Greek religion are ruled out. Furthermore, on any interpretation of $\mathrm{T}_{1}$, if morally virtuous activities are somehow unworthy of true divinity, the salacious escapades of popular Greek deities are all the more unworthy. The only beings within Aristotle's philosophical system that behave in the way that he seems to envision in $\mathrm{T}_{1}$ are the unmoved mover and perhaps certain celestial objects, if indeed the latter contemplate at all.

With the range of Aristotle's divine beings in view, let us return to our question: Do these beings have the capacities involved in theoretical wisdom, namely

25. Metaph. 12. 8 raises the question of how many divine unmoved movers there might be. Aristotle's view about this is notoriously unclear. I will assume that any divine unmoved movers other than the first unmoved mover would share at least some of the features of the first unmoved mover that I argue are individually sufficient for type-distinctness from human contemplation.

26. This is argued at length by Segev (2017: chs. 1 and 3). Contrast Bodéüs (1992: ch. 5).

27. Johnson (2005: 262) and Segev (2017: 18) cite the Metaph. 12. 8 passage in support of the idea that Aristotle does not believe in the popular Greek deities, but rather sees popular beliefs as pointing to the truth that there are divine celestial objects. 
the relevant sort of nous (the developed capacity to grasp first principles intuitively as first principles) and epistêmê (the developed capacity for scientific demonstration from first principles)?

\subsection{The Unmoved Mover}

Let us start with why the unmoved mover cannot have epistêmê. ${ }^{28}$ First, epistêmê always has an object other than itself (Metaph. 12. 9, 1074 $\left.{ }^{\mathrm{b}} 35\right)$, whereas the unmoved mover's thinking never does $\left(1074^{\mathrm{b}} 25-34,1075^{\mathrm{a}} 3-5\right)$. That is because the unmoved mover thinks only about its own thinking. Epistêmê scientifically demonstrates from first principles, which must be distinct from what is demonstrated from them. That is why Aristotle feels the need to distinguish between the objects of nous, which grasps first principles, and the objects of epistêmê, which, since it is distinct from nous, must have objects distinct from those of nous (Post. An. 2. 19, $\left.100^{b} 5-17\right)$. One does not have nous of what is demonstrated, but rather only of first principles. Likewise, one does not have epistêmê of first principles, but only of what is demonstrated from them. None of this would be possible if demonstration were purely reflexive. Since demonstration is not purely reflexive, epistêmê has an object other than itself, and therefore is incompatible with the unmoved mover's thinking. Since the unmoved mover is its thinking, the unmoved mover could not have epistêmê.

The second reason why the unmoved mover could not have epistêmê is that manifestations of epistêmê are composite, whereas the unmoved mover's thinking is not (Metaph. 12. 7, 1073 $\left.{ }^{\mathrm{a}} 6-7 ; 9,1074^{\mathrm{b}} 33^{-34}\right)$. Manifestations of epistêmê are composite because demonstration requires the conjunction of distinct premises. A demonstration is a whole with parts, and thinking of such parts in the way that demonstration requires would involve change between these parts. The demonstrator must shift mentally from a premise or premises to what is demonstrated from them. But such change in thought is impossible for the unmoved mover. That is because if the unmoved mover's thinking were to shift from anything but itself, it would be thinking about something worse than it is. But then it would not be thinking about the best and most divine thing of all, and then would not be the best and most divine sort of thing (Metaph. 12. 9, 1074 ${ }^{\mathrm{b}}$ 21-35). Any change in the unmoved mover's thinking would be a change for the worse, but it cannot change for the worse. ${ }^{29}$ So again, the unmoved mover cannot have epistêmê.

28. Parts of the arguments that follow can be found in Beere (2010: 27-30), Brunschwig (2000: 296-301), Herzberg (2013: ch. 4), Herzberg (2016), Menn (2012: 446-447), Modrak (1991: 770), and Wedin (1988: 229-245).

29. A change from thinking to not thinking would also be a change for the worse since Aristotle supposes the unmoved mover's thinking to be the best activity. That is why, as Thorsrud (2015: 352) mentions, human contemplation can be engaged in intermittently whereas the unmoved 
Indeed, the unmoved mover could not even have nous in the sense that is required for theoretical wisdom. That sort of nous grasps multiple first principles of a demonstrative science (Post. An. 2. 19, $100^{\mathrm{b}}{ }^{-1}-17$, Metaph. 1. 2, $982^{\mathrm{a}} 19^{-}{ }^{\mathrm{b}} 10, N E$ 6. 6). ${ }^{30}$ But, as already mentioned, the unmoved mover's thought is not composite, and so it cannot grasp multiple first principles.

Furthermore, the unmoved mover's thinking involves no images (phantasmata) since it cannot involve anything but itself and it is not an image, and since interaction with images requires a perceiving soul, which the unmoved mover lacks. However, human grasp of first principles must involve images (DA 3 . 7, 431 ${ }^{\mathrm{b}} 2-9,3.8,432^{\mathrm{a}} 3-9$; cf. Post. An. 2. 19), at least while embodied (DA 3. 7, $\left.431^{b} 17-19\right) \cdot{ }^{31}$ Precisely how it is possible (and why it is necessary) for us to grasp first principles by way of images is controversial, but it is clear that Aristotle thinks that at least in our present condition our path to grasping first principles goes through images, whereas the unmoved mover's thinking cannot do so. ${ }^{32}$ For this reason, too, the unmoved mover cannot have nous of the sort required for theoretical wisdom.

\subsection{Celestial Objects}

Let us now turn to celestial objects. The primary apparent evidence that any of them contemplates is $\mathrm{T}_{3}$ (Metaph. 12. $7,1072^{\mathrm{a}} 19-30$ ), which explains what sort of mover is required to cause the eternal, unvarying rotation of at least the outermost celestial sphere:

mover's contemplation cannot. The difference in duration of divine and human contemplation thus depends on a difference in type.

30. This is mentioned by Burnyeat (2008: 27-28), who adds that the sort of nous required for theoretical wisdom must involve grasping principles as principles of demonstrations, which of course the unmoved mover's thinking could not do. Burnyeat infers from this that nous in general (whether human or divine) could not be about something lacking distinguishable parts. He draws the astonishing conclusion that, in spite of the evidence of Metaph. 12. 9, the unmoved mover's thinking is of something composite. This view is also held by Kahn (1981: 412-414), Lear (1988: 295) and Silverman (2010: 92-93). Beere (2010: 28 n. 47) argues that such a proposal faces grave difficulties. It would do far less violence to the text to conclude, as I do, that the unmoved mover's thinking does not involve the sort of nous required for theoretical wisdom. It is surprising that Silverman does not do so since he eventually embraces the view that immediately follows from this that human and divine contemplation are distinct not merely in duration and continuity but also in type (2010: 93).

31. This is mentioned by Herzberg (2016: 167), Modrak (1991: 770-771), Ross (1953: 379), Segev (2017: 109), and Wedin (1988: 244-245) as a reason why the unmoved mover's thinking cannot feature nous considered as grasping first principles.

32. Cohoe (2016: 352$)$ argues that the unmoved mover's thinking cannot involve images. His paper as a whole discusses in detail the extent to which, and reasons why, human thinking does involve images. 
1) Since this is possible, and unless it were so then the world would be from night and 'all things together' and from not-being, these difficulties are resolved, and there is something that always is moved with an unceasing motion, which motion is circular (and this is clear not only by argument but in fact), with the result that the first heaven would be eternal. 2) Therefore, there is also something that moves it. 3) Since what is moved and moves is also intermediate $[\ldots]^{33} 4$ ) there is something that moves without being moved, being eternal, a substance, and actuality. 5) And an object of desire and an object of thought move in this way: they move

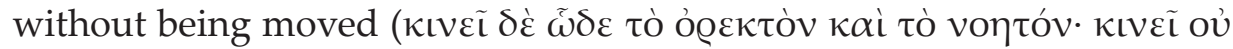

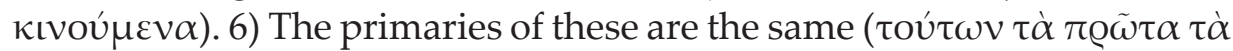

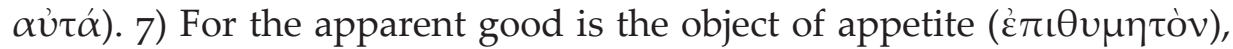

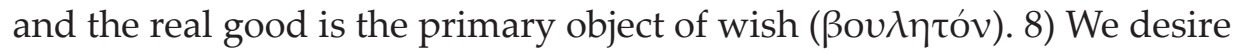
something because it seems good rather than it seeming good because

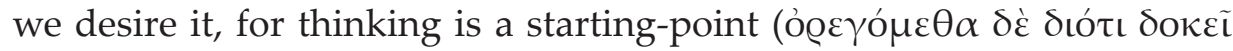

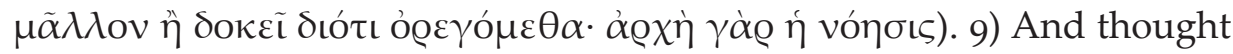

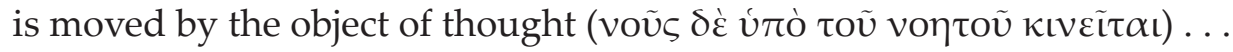

One might suppose that Aristotle here says that the unmoved mover is literally an object of desire and of thought for the outermost celestial sphere ("the first heaven"). A problem for such an interpretation is that he also says that the elements and plants "desire" to share in the divine and eternal motion (GC 2. 10, $\left.336^{\mathrm{b}} 27-337^{\mathrm{a}} 7 ; D A 2.4,415^{\mathrm{a}} 25^{-\mathrm{b}} 7\right)$, but on his view they do not literally desire anything. ${ }^{34}$ Alternatively, we might think that Aristotle is simply giving familiar examples of unmoved movers, objects of desire and objects of thought, in order to illustrate what sort of mover is required to explain the outermost celestial sphere's eternal motions, namely, something that moves without being moved. On this second interpretation, the sphere would not literally desire or think about the unmoved mover, and so a fortiori would not contemplate it. 35 Even on

33. The OCT marks a lacuna here. Laks (2000: 219) thinks that we need not take there to be a lacuna since the transmitted text gives all that is needed to make the argument work. My translation of sentence 3 follows his.

34. This point is made forcefully by Caston (1999: 217).

35. Simplicius reports in his commentary on DC 2. $2,285^{\mathrm{a}} 27-30$ that certain respectable but unnamed ancient commentators attributed to Aristotle the view that celestial objects do not have rational souls (388.16-19) and therefore cannot think about anything. Blyth (2015: 429 n. 5) thinks that Theophrastus and Alexander of Aphrodisias had this interpretation. For the long and complicated history of debate among Greek, Arabic, and Latin commentators on Aristotle about what sorts of psychic capacities, if any, celestial objects have, see Wolfson (1973). Among recent commentators, Broadie (1993: 406) argues that the unmoved mover does not cause the movement of any celestial object by literally being an object of thought for it. According to her, this is because the unmoved mover is related to the outermost celestial sphere as soul is related to body, and its causality of the movement of this sphere is efficient rather than final. Roughly this view is also 
the first interpretation, the unmoved mover need be only an object of whatever sort of thought is required for it to be desired (rather than theoretical thought) for the outermost celestial sphere $\left(D A 3.10,433^{a} 15-20\right) \cdot{ }^{36}$ That Aristotle argues for an unmoved mover on the ground that it is necessary to explain the locomotion of celestial objects makes better sense, in fact, if the unmoved mover is an object of such thought for the outermost celestial sphere rather than of theoretical thought. That is because, according to him, objects of desire, and precisely not objects of theoretical thought, are causes of locomotion ( $D A$ 3. 10).37 Such considerations are clearly on Aristotle's mind in $T_{3}$, for sentences (3)-(9) echo several passages from $D A 3 \cdot 10.3^{8}$

$\mathrm{T}_{4}: D A 3 \cdot 10,433^{\mathrm{b}} 13-1839$

The following three are involved in movement: first, the mover, second, that by which it moves things, and third, the moved. There are two sorts of movers, one unmoved and one that moves and is moved. The one that is unmoved is the good achievable in action ( that moves and is moved is the desiring part (for what is moved is moved in so far as it desires, and active desire is a sort of movement), and the one that is moved is the animal.

$\mathrm{T}_{5}: D A 3 \cdot 10,433^{\mathrm{a}} 27-29$

That is why what moves is always the object of desire, and this is either the good or the apparent good, not every good, but rather the good

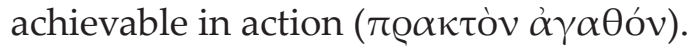

articulated by Bodéüs (1992: ch. 2). Blyth (2015: 455-463) contends that no celestial object contemplates the unmoved mover because no celestial object has a rational soul. His conclusion is thus similar to that of Broadie and Bodéüs, but derived from premises several of which are incompatible with theirs. Blyth thinks that T3, within its context in Metaph. 12. 7, suggests only that the unmoved mover is an object of desire and thought for the thinking that is its essence (2015: 456-459). The outermost celestial sphere does not have a soul at all, let alone a rational soul, but is moved because the aithêr of which it is composed naturally (not intentionally) responds to the unmoved mover by rotating, a response that Aristotle describes in erotic terms in Metaph. 12.7 (2015: 460462). Roughly this view was taken in antiquity to be supported by Aristotle's remarks about aithêr in DC 1. 2, as is noted not only by Blyth (2015: 441), but also by Wolfson (1973: 23-24).

36. See Laks (2000: 221).

37. One might think that it is inappropriate to appeal to Aristotle's remarks about desire and thought in $D A$ 3. 10 to understand what sort of cognitive activity (if any) is characteristic of celestial objects for the reason that the cognitive activity of superlunary beings is so different from that of humans that his remarks in $D A$ cannot be supposed to apply to such beings. If that is correct, then my conclusion of this section follows.

38. Laks (2000: 220, 223-224) thinks that $T_{3}$ offers a "condensed version" of parts of DA 3. 10.

39. Bonitz (1848: 496) proposes that this passage can help us understand what may have filled the lacuna in $\mathrm{T}_{3}$, sentence 3 . 
T6: $D A$ 3. 10, $433^{\mathrm{a}} 17-20$

As a result, these two reasonably appear to be movers, namely, desire and practical thought. For the object of desire moves, and because of this thought moves, since its starting-point is the object of desire.

So, whether one adopts the first or the second interpretation of $\mathrm{T}_{3}$, one will not have much reason to say that any celestial object engages in theoretical thought about the unmoved mover, let alone that any meets Aristotle's strict criteria for theoretical wisdom. In fact, even if one wants to insist that the unmoved mover is an object of theoretical thought for celestial objects, these objects could not have theoretical wisdom. Here is why. Either the continuous, simple, and unvarying movement of the celestial objects is explained by theoretical thinking about the unmoved mover or it is not. $4^{\circ}$ If it is not, then nothing about the structure of Aristotle's argument would lead us to suppose that they engage in theoretical thought about the unmoved mover in the first place, since the phenomenon of their continuous, simple, and unvarying movement is what the unmoved mover is meant to explain. If it is explained by theoretical thinking about the unmoved mover, then since their movement is supposed to be continuous, simple, and unvarying, they could have neither nous nor epistêmê in the way that these figure in theoretical wisdom. Whereas the sort of nous that figures in theoretical wisdom grasps multiple first principles as part of a demonstrative science, the movement of any given celestial object could not be explained by its grasping multiple first principles. Else it would not be continuous, simple, and unvarying. Furthermore, no celestial object could be capable of demonstrating anything from such first principles because that would involve the potential to change from thinking about one thing to thinking about another. Since, ex hypothesi, its movement is explained by theoretical thinking about the unmoved

40. This disjunction requires some clarification in the case of celestial spheres other than the outermost, which is the only one mentioned in $\mathrm{T}_{3}$, the principal source of putative textual evidence that any celestial object contemplates. The movement of the outermost sphere is comparatively easy to understand, for it simply rotates. To describe the movements of the spheres nested within the outermost sphere, Aristotle in Metaph. 12. 8 introduces his own version of the cosmology developed by Eudoxus and refined by Callipus: The spheres nested within the outermost sphere have their proper movement, which, as in the case of the outermost sphere, is continuous, simple, unvarying rotation. However, since the spheres are nested with no void between them, they are attached, but at different angles. This means that the movement of each sphere further out will affect the movement of each sphere further in. So, as Aristotle notes in DC 2. 12, spheres other than the outermost will have multiple movements. Nonetheless, its proper movement is rotation, and this rotation (but not whatever influences may be transmitted by spheres further out) is directly explained with reference to an unmoved mover. So, the only movement of any celestial object that an unmoved mover is supposed to explain directly is continuous, simple, unvarying rotation. Judson (2015) provides a detailed discussion of these and other aspects of Aristotle's account. 
mover, having the potential for change in object of thought would entail having the potential for change in movement. But nothing with continuous, simple, and unvarying movement could have such potentiality. Aristotle is right, then, in offering no suggestion that celestial objects are capable of scientific demonstration from first principles. So, again, celestial objects cannot have theoretical wisdom, and therefore cannot engage in contemplation of the same type as that in which human beings engage.

There is yet another reason to think that celestial objects lack the sort of nous required for theoretical wisdom. As mentioned above, that sort of nous grasps first principles of a demonstrative science by way of images (phantasmata). We have already seen that the unmoved mover is incapable of this, but what about celestial objects? To grasp first principles by way of images, one has to have imagination (phantasia). Imagination requires a perceptive soul $\left(D A 3 \cdot 3,427^{\mathrm{b}} 14^{-}\right.$ 16). It is far from obvious that celestial objects have perceptive souls, though some have thought that they do. ${ }^{4^{1}}$ Suppose for the sake of argument that they do have perceptive souls. Then, if they have desire then they would also have imagination ( $D A$ 3. 10, $\left.433^{\mathrm{b}} 28-29\right)$. Since imagination is regarded by Aristotle as a kind of thought (nous) (DA 3. 10, 433 $\left.3^{\mathrm{a}} 9-12, M A 6,700^{\mathrm{b}} 17-22\right)$, those who regard $\mathrm{T}_{3}$ as insinuating that the unmoved mover is literally an object of desire and thought for the outermost celestial sphere would be left with no reason to suppose that this requires the sphere to have theoretical thought. ${ }^{42}$ After all, nonrational animals are capable of locomotion for the sake of objects of desire and thought (where imagination is the kind of thought at issue). Thus, $\mathrm{T}_{3}$ would give no support for the idea that celestial objects have the sort of nous required for theoretical wisdom.

The foregoing arguments show that neither the unmoved mover nor any other divine beings the existence of which Aristotle recognizes could engage in contemplation that is type-identical with human contemplation. If that is right, then the argument from divine contemplation equivocates on 'contemplation.'

41. See Cohoe (in press), Segev (2017: ch. 3), and Wolfson (1973: 34-40) for general discussion about debates concerning the psychic capacities (or lack thereof) of celestial objects.

42. One might think that there would still be a reason to suppose that the outermost celestial sphere has theoretical thought if it has any sort of thought: the sphere is divine and we are not, so its activity should be better than ours is. But if we can contemplate and the sphere cannot, but rather engages only in another sort of thought, then its activity would not be better than ours is. I reply as follows. First, Aristotle gives us no reason to suppose that a divine being's thought (of whatever sort) could not be better than a human's theoretical thought unless we assume that divine and human contemplation are type-identical. Second, the sphere's activity could be better than ours in virtue of being continuous, uninterrupted, and unforced (given that, if it is composed of aithêr, it does not have to exert effort the way that beings composed of the other four elements do). Being theoretical is not the only applicable determinant of being better. 


\subsection{Divine Sophia in Metaphysics 1. 2}

I have been arguing that the divine beings that Aristotle recognizes could not, according to him, have and manifest theoretical wisdom, sophia, as it is described in his ethical works. Aristotle does, though, speak of divine sophia in Metaph. 1. 2. There are two reasons why this is unproblematic for my thesis. 43 First, as Broadie (2012) argues at length, the sophia that he there describes is not the virtue that he discusses in his ethical works, but rather a department of knowledge concerned specifically with answers to an array of foundational questions. So, even if the divine beings that Aristotle recognizes had this sort of sophia, it would tell us nothing about whether they had the virtue described in his ethical works and would therefore have no obvious tendency to generate the sort of conflict with the function argument that the argument from divine contemplation encapsulates.

Second, there are reasons to believe that even this sort of sophia is not attributed both to humans and to the divine beings that Aristotle recognizes (rather than a divine being as commonly conceived). Human sophia in Metaph. 1. 2 is understood as knowledge of causes in general of all things as far as this is possible $\left(982^{\mathrm{a}} 8-10,{ }^{\mathrm{a}} 21-^{\mathrm{b}} 7\right)$. These causes include, but are not limited to, final causes $\left(982^{\mathrm{b}} 9-10,1.3,983^{\mathrm{a}} 24-32\right)$. Indeed, they could not be limited to final causes since human sophia here includes knowledge of causes in mathematics $\left(982^{\mathrm{a}} 23-28\right.$, $\left.983^{\mathrm{a}} 15-16\right)$, which subject does not feature final causes. To the extent that Aristotle's divine beings have knowledge of causes (as such) at all, it includes neither causes in mathematics nor material causes of existing things. But Aristotle calls "this sort of knowledge," knowledge of causes in general, divine ( $\left.983^{\mathrm{a}}{ }^{5-7}\right)$. How, then, could he do so coherently? "This sort of knowledge" (toiautê), the sort called "divine," could perhaps be intended to cover two type-distinct forms of sophia, both of which count as divine because they are a) concerned with at least one divine cause and b) "free" in the sense that they are useless for further pursuits. Human sophia would be concerned with causes in general, including, but not limited to, the unmoved mover, and the unmoved mover's sophia would be concerned with itself exclusively. If this is what Aristotle means, then he is not committed in Metaph. 1. 2 to the type-identity of any sort of sophia, let alone the sort at issue in his ethical works, possessed by humans and divine beings. If, though, Aristotle means by "this sort of knowledge" (toiautê) that humans and "the god" are supposed to have sophia of the same type, which entails that they are concerned with the same set of things, then I see no plausible way around Ross's (1953: 123) conclusion that he must here have in mind a god as popu-

43. Thanks to an anonymous reviewer for suggesting discussion of why this chapter is unproblematic for my view. 
larly conceived, not his unmoved mover. That is because, as we have seen, the unmoved mover thinks only of itself, not of mathematics or the material causes of existing things. ${ }^{44}$ So, again, Aristotle would not be attributing type-identical sophia both to humans and to the divine beings that he recognizes.

\section{An Aristotelian Parallel: The Argument from Animal Activities}

One may wonder how likely Aristotle would be to respond to the argument from divine contemplation in this way if he had been explicitly confronted with it. We can get some insight into this by considering the fact that Aristotle already makes a very similar move to address a parallel argument, the argument from animal activities:

i. If practically wise and morally virtuous activities are proper to human beings, only human beings are capable of practically wise and morally virtuous activities.

ii. If some animals are capable of practically wise and morally virtuous activities, then it is false that only human beings are capable of practically wise and morally virtuous activities.

iii. Some animals are capable of practically wise and morally virtuous activities.

iv. So, it is false that only human beings are capable of practically wise and morally virtuous activities.

44. Broadie (2012: 66) offers the suggestion that Aristotle's unmoved mover could be in view here if it thinks about itself as cause of eternal things and so do humans. This suggestion has the following weaknesses. First, there is no positive evidence that Aristotle understood the unmoved mover's thinking in this way. Second, even if human sophia concerns the unmoved mover as cause of eternal things, the chapter indicates that human sophia is concerned with other things about which the unmoved mover would not be thinking, such as the material causes of celestial bodies. Third, it is unlikely that Aristotle would countenance such a description of the unmoved mover's thought. That is because, as we have seen, he believes that the unmoved mover must think about what is best and nothing else. According to Broadie's suggestion, both humans and the unmoved mover would think about the unmoved mover not as an entity in itself, but rather as related to its principal effects. But if thinking of the unmoved mover as related to its principal effects is sufficiently different from thinking of it as an entity in itself to accommodate, as Broadie wants to do, the plurality of first principles and causes with which human sophia is concerned, then the unmoved mover, in thinking of itself as related to its principal effects, would not be thinking of what is best, namely, itself as an entity in itself. That is because if something is thought of qua related to something else, it is thought of as having an essence mutually dependent on that to which it is related (Cat. 7, 8 $31-32)$. But, as we have seen, one of Aristotle's reasons for thinking that the unmoved mover is best is that its essence depends on nothing else. 
v. Therefore, practically wise and morally virtuous activities are not proper to human beings.

If Aristotle accepts this conclusion, then he cannot argue as he does either in $N E$ 1. 7 or 10. 8, for both of those arguments explicitly depend on the claim that practically wise and morally virtuous activities are proper to human beings. Aristotle clearly accepts (iii), for he attributes practically wise and morally virtuous activities to some animals (HA 8. 1, 588 ${ }^{\mathrm{a}}{ }_{18}-^{\mathrm{b}} 3$, Metaph. 1. 1, 980 ${ }^{\mathrm{b}_{21}-22}$, NE 6. 7, 1141 $\left.{ }^{\mathrm{a}} 26-28\right)$. But he does not accept the conclusion; he says that mature humans alone can have virtues, and animals cannot (NE 7. 1, 1145 $\left.{ }^{\mathrm{a}} 25^{-26}\right)$. Aristotle's position is consistent because he thinks that 'practically wise and morally virtuous activities' is predicated equivocally of humans and animals (NE 7 . 6 , $\left.1149^{\mathrm{b}} 31-32\right)$. He thinks that some animals perform activities that he is willing to call practically wise or morally virtuous (e.g., courageous), but in a sense that differs from that in which human beings can perform practically wise and morally virtuous activities. He distinguishes between attributing type-identical virtues and attributing merely analogous virtues, and says that we attribute the latter but not the former to humans and animals (HA 8. 1, 588 ${ }^{\mathrm{a}} 18^{-{ }^{\mathrm{b}}} 3$ ).

Kraut (1979: 472-474) anticipates in broad outline the strategy of responding to the argument from divine contemplation by saying that human and divine contemplation differ in type (though not for my reason for saying that they do, namely that the former but not the latter is a manifestation of theoretical wisdom), as well as its parallel with Aristotle's response to the argument from animals' practically wise and morally virtuous activities. He gives two arguments against it. Here is the first, quoted in full:

Is this a satisfactory way for Aristotle to maintain the thesis that contemplation is at least part of our function? I think not. For suppose we could overcome our human limitations and engage in precisely that kind of contemplation which Aristotle's god enjoys. Even though that would be a better kind of contemplation, it could no longer be even part of our function to engage in it, because it would no longer be peculiar to us. So, Aristotle would have to counsel us not to participate in this improved form of contemplation, in spite of its superiority to the form we currently can enjoy. I find this position paradoxical, and I am reluctant to believe that Aristotle is committed to it. (1979: 473)

I share Kraut's reluctance to believe that Aristotle is committed to this position, but that is because Aristotle himself says that scenarios like the one that Kraut envisions amount to imagining oneself away (NE 8. 7, 1159 ${ }^{\mathrm{a}} 5^{-12,}$ 9. 4, 
1166 $19-22) .45$ Kraut invites us to imagine that we could engage in the unmoved mover's sort of contemplation, which Kraut is granting for purposes of this argument is distinct in type from human contemplation. But since the unmoved mover and its contemplation are strictly identical, the only way to engage in that sort of contemplation is to be that sort of contemplation. So, we are invited to imagine that we are not human, but rather the unmoved mover. Kraut's counterfactual claim that if we were the unmoved mover then the human function would not be applicable to us is obviously correct, since its antecedent and consequent are both necessarily false, and my argument contains nothing that would contravene it.

The second of Kraut's arguments, again quoted in full, is this:

If Aristotle thinks that contemplation is peculiar to us because human and divine contemplation differ in kind, then he opens himself to this objection: 'In the function argument you have set up a test to determine which good or goods happiness consists in. Doesn't ethically virtuous activity pass that test with higher marks than your own candidate, contemplation? After all, you are looking for what sets human beings off from all other things, and the ethical virtues do this to a greater extent than contemplation. When a human being is just or generous or temperate, he is more unlike anything else than when he contemplates. For the gods, properly conceived, are totally devoid of ethical qualities. And though some animals have traits akin to virtue and vice, these qualities differ radically from their human counterparts; a person's virtues derive in part from reason, a faculty animals lack. How much closer, then, are human and divine contemplation, since both are activities of the same kind of faculty, reason. Though the function argument and your defense of contemplation are mutually consistent, your search for the peculiarly human ought to have led you to make ethical activity the topmost good.' (1979: 473-474)

The problem with this second argument is that Kraut simply assumes that human and divine contemplation are manifestations of a faculty that they share. But as I have argued, whereas human contemplation is a manifestation of theoretical wisdom, divine contemplation could not be a manifestation of any such thing. The unmoved mover could not share either the sort of nous or the sort of epistêmê that theoretical wisdom involves, and so could not have theoretical wisdom of the same type that human beings can possess. As for celestial objects,

45. Thorsrud (2015: 358), Walker (2018: 96), and Whiting (1988: 47 n. 19) remark and explain the incoherence of wishing that oneself or one's friend were divine. 
even if they have rational souls at all and we insist with no textual grounding on describing their thought as theoretical rather than practical, they still would not share with humans the sort of nous or epistêmê required for theoretical wisdom. In short, Kraut's argument does not take account of the reason for saying that human and divine contemplation are type-distinct, which, as I have argued, is that whereas human contemplation is a manifestation of theoretical wisdom, divine contemplation cannot be.

\section{Conclusion}

I began by introducing the argument from divine contemplation as a threat to Aristotle's claims in NE 1. 7 and 10. 7-8 that contemplation is proper to human beings. Those claims are threatened if humans and divine beings engage in the same type of contemplation. Section 2 surveyed existing responses to the argument from divine contemplation, all of which assume that human and divine contemplation are type-identical, and argued that another solution would be preferable to these. Section 3 contended that the principal apparent textual evidence for the type-identity of human and divine contemplation is inconclusive and is interpreted more conservatively as suggesting that human and divine contemplation are merely similar. Section 4 argued that the divine beings recognized by Aristotle, namely the unmoved mover and celestial objects, cannot engage in the same type of contemplation as human beings can. That is because human contemplation is a manifestation of theoretical wisdom, a virtue that includes the further virtues of epistêmê and nous (of a particular kind), but Aristotle's divine beings cannot possess or manifest theoretical wisdom because they cannot possess or manifest epistêmê or nous of the relevant kind. The argument from divine contemplation is invalid because it equivocates on two different uses of 'contemplation,' one designating a human activity, the other a divine activity. Section 5 showed that such a response to the argument from divine contemplation closely parallels a response that Aristotle gives to a similar argument from animals' practically wise and morally virtuous activities: such activities are proper to human beings because the activities ascribed to animals are not of the same type, but rather are called practically wise and morally virtuous by analogy to human activities. The upshot is that we can take Aristotle at his word: contemplation, at least of the type that is a manifestation of theoretical wisdom, is proper to human beings. 


\section{Acknowledgments}

I would like to thank David Charles, Brad Inwood, Mark Schiefsky, Mor Segev, Harald Thorsrud, two anonymous reviewers, and the Area Editor for this journal, as well as audiences in October 2018 at the Bryn Mawr Classics Colloquium and a conference on Happiness and Ethics in the Aristotelian Tradition sponsored by Providence College and the University of Notre Dame, for feedback that improved this paper. I am also grateful for the generous support of Harvard University's Center for Hellenic Studies, the John and Daria Barry Foundation, and the University of Chicago.

\section{References}

Ackrill, John L. (1997). Aristotle on Eudaimonia. In John L. Ackrill (Ed.), Essays on Plato and Aristotle (179-200). Oxford University Press.

Aufderheide, Joachim (2015). The Content of Happiness: A New Case for Theôria. In Joachim Aufderheide and Ralf M. Bader (Eds.), The Highest Good in Aristotle and Kant (36-59). Oxford University Press. https://doi.org/10.1093/acprof:o so/9780198714019.001.0001

Aquinas, Thomas (1950). In Duodecim Libros Metaphysicorum Aristotelis Expositio (Vol. 2). (M. R. Cathala, O.P. and Raymund M. Spiazzi, O.P., Eds.) Marietti.

Averroes (1984). Ibn Rushd's Metaphysics: A Translation with Introduction of Ibn Rushd's Commentary on Aristotle's Metaphysics, Book Lām. (Charles Genequand, Trans.) Brill.

Beere, Jonathan (2010). Thinking Thinking Thinking: On God's Self-Thinking in Aristotle's Metaphysics $\Lambda .9$. Retrieved from https://www.philosophie.hu-berlin.de/en/ ancient-philosophy/hpold/downloads/beere-thinking-thinking/view

Blyth, Dougal (2015). Heavenly Soul in Aristotle. Apeiron, 48(4), 427-465. https://doi. org/10.1515/ apeiron-2013-0037

Bodéüs, Richard (1992). Aristote et la Théologie des Vivants Immortels. Bellarmin. https:// doi.org/10.7202/027352ar

Bonitz, Hermann (Ed.). (1848). Aristotelis Metaphysica (Vol. 1). A. Marcus.

Bordt, Michael (2006). Aristoteles' Metaphysik XII. Wissenschaftliche Buchgesellschaft.

Broadie, Sarah (1993). Que Fait le Premier Moteur d'Aristote? (Sur la théologie du livre Lambda de la «Métaphysique»). Revue Philosophique de la France et de l'Étranger, 183(2), 375-411. https://doi.org/10.3917/rphi

Broadie, Sarah (2012). A Science of First Principles: Metaphysics A 2. In Carlos Steel and Oliver Primavesi (Eds.), Aristotle's Metaphysics Alpha: Symposium Aristotelicum (43-67). Oxford University Press. https://doi.org/10.1093/acprof:oso/9780199639984.001.0001

Brunschwig, Jacques (2000). Metaphysics $\Lambda$ 9: A Short-Lived Thought-Experiment? In Michael Frede and David Charles (Eds.), Aristotle's Metaphysics Lambda: Symposium Aristotelicum (275-306). Oxford University Press.

Burnyeat, Myles F. (2008). Aristotle's Divine Intellect. Marquette University Press.

Bush, Stephen S. (2008). Divine and Human Happiness in Nicomachean Ethics. The Philosophical Review, 117(1), 49-75. https://doi.org/10.1215/00318108-2007-024 
Caston, Victor (1999). Aristotle's Two Intellects: A Modest Proposal. Phronesis, 44(3), 199227. https://doi.org/10.1163/15685289960500033

Charles, David (2017a). Aristotle on Virtue and Happiness. In Christopher Bobonich (Ed.), The Cambridge Companion to Ancient Ethics (105-123). Cambridge University Press. https://doi.org/10.1017/9781107284258.007

Charles, David (2017b). Aristotle's Nicomachean Function Argument: Some Issues. Philosophical Inquiry, 41(2), 95-104. https://doi.org/10.5840/philinquiry2017412/318

Cohoe, Caleb (2014). Nous in Aristotle's De Anima. Philosophy Compass, 9(9), 594-604. https://doi.org/10.1111/phc3.12156

Cohoe, Caleb (2016). When and Why Aristotle Needs Phantasmata: A Moderate Interpretation of Aristotle's De Memoria and De Anima on the Role of Images in Intellectual Activities. Phronesis, 61(3), 337-372. https://doi.org/10.1163/15685284-12341311

Cohoe, Caleb (in press). Living Without a Soul: Why God and the Heavenly Movers Fall Outside of Aristotle's Psychology. Phronesis. https://doi.org/10.1163/1568528412342116

Cooper, John M. (1975). Reason and Human Good in Aristotle. Harvard University Press.

Curzer, Howard J. (1990). Criteria for Happiness in Nicomachean Ethics I 7 and X 6-8. Classical Quarterly, 40(2), 421-432. https://doi.org/10.1017/S0009838800042993

Curzer, Howard J. (2012). Aristotle on Virtue. Oxford University Press. https://doi. org/10.1093/acprof:oso/9780199693726.001.0001

Dahl, Norman O. (2011). Contemplation and Eudaimonia in the Nicomachean Ethics. In Jon Miller (Ed.), Aristotle's Nicomachean Ethics: A Critical Guide (66-91). Cambridge University Press. https://doi.org/10.1017/CBO9780511977626.005

Gauthier, René Antoine and Jean Yves Jolif (1970). L'Éthique à Nicomaque: Introduction, traduction et commentaire (2nd ed., Vol. 2). Publications Universitaires. https://doi. org/10.1017/s0009840x0021353x

Gerson, Lloyd P. (1990). God and Greek Philosophy: Studies in the Early History of Natural Theology. Routledge. https://doi.org/10.2307/2185804

Guthrie, W. K. C. (1981). A History of Greek Philosophy (Vol. 6). Cambridge University Press.

Herzberg, Stephan (2013). Menschliche und göttliche Kontemplation: Eine Untersuchung zum bios theoretikos bei Aristoteles. Universitätsverlag Winter.

Herzberg, Stephan (2016). God as Pure Thinking. An Interpretation of Metaphysics $\Lambda$, 1072b14-26. In Christoph Horn (Ed.), Aristotle's Metaphysics Lambda-New Essays (157-180). De Gruyter. https://doi.org/10.1515/9781501503443-009

Irwin, Terence (1980). The Metaphysical and Psychological Basis of Aristotle's Ethics. In Amélie Oksenberg Rorty (Ed.), Essays on Aristotle's Ethics (35-53). University of California Press. https://doi.org/10.1086/293711

Joachim, Harold Henry (1951). Aristotle, The Nicomachean Ethics: A Commentary. Clarendon Press.

Johnson, Monte Ransome (2005). Aristotle on Teleology. Clarendon Press. https:/doi.org/ $10.1093 / 0199285306.001 .0001$

Judson, Lindsay (2015). Aristotle's Astrophysics. Oxford Studies in Ancient Philosophy, 49, 151-192. https://doi.org/10.1093/acprof:oso/9780198749516.003.0005

Kahn, Charles H. (1981). The Role of Nous in the Cognition of First Principles in Posterior Analytics II.19. In Enrico Berti (Ed.), Aristotle on Science: The Posterior Analytics (385414). Antenore. 
Keyt, David (1983). Intellectualism in Aristotle. In John P. Anton and Anthony Preus (Eds.), Essays in Ancient Greek Philosophy (Vol. 2, 364-387). State University of New York Press.

Kosman, Aryeh (2000). Metaphysics $\Lambda$ 9: Divine Thought. In Michael Frede and David Charles (Eds.), Aristotle's Metaphysics Lambda: Symposium Aristotelicum (307-326). Oxford University Press.

Kraut, Richard (1979). The Peculiar Function of Human Beings. Canadian Journal of Philosophy, 9(3), 467-478. https://doi.org/10.1080/00455091.1979.10716263

Kraut, Richard (1989). Aristotle on the Human Good. Princeton University Press.

Laks, André (2000). Metaphysics $\Lambda$ 7. In Michael Frede and David Charles (Eds.), Aristotle's Metaphysics Lambda: Symposium Aristotelicum (207-243). Oxford University Press.

Lawrence, Gavin (2001). The Function of the Function Argument. Ancient Philosophy, 21(2), 445-475. https://doi.org/10.5840/ancientphil200121227

Lear, Gabriel Richardson (2004). Happy Lives and the Highest Good: An Essay on Aristotle's Nicomachean Ethics. Princeton University Press. https://doi. org/10.1515/9781400826087

Lear, Jonathan (1988). Aristotle: The Desire to Understand. Cambridge University Press. https://doi.org/10.1017/CBO9780511570612

Menn, Stephen (2012). Aristotle's Theology. In Christopher Shields (Ed.), The Oxford Handbook of Aristotle (422-464). Oxford University Press. https://doi.org/10.1093/ox fordhb/ 9780195187489.013 .0017

Modrak, Deborah K. W. (1991). The Nous-Body Problem in Aristotle. The Review of Metaphysics, 44(4), 755-774. https://doi.org/revmetaph199144457

Nagel, Thomas (1972). Aristotle on Eudaimonia. Phronesis, 17(3), 252-259. https://doi. org/10.1163/156852872x00079

Norman, Richard (1969). Aristotle's Philosopher-God. Phronesis, 14(1), 63-74. https:// doi.org/10.1163/156852869x00046

Reece, Bryan C. (2019). Aristotle's Four Causes of Action. Australasian Journal of Philosophy, 97(2), 213-227. https://doi.org/10.1080/00048402.2018.1482932

Reece, Bryan C. (2020). Are There Really Two Kinds of Happiness in Aristotle's Nicomachean Ethics? Classical Philology, 115(2), 270-280. https://doi.org/10.1086/707809

Roochnik, David (2009). What is Theoria? Nicomachean Ethics Book 10.7-8. Classical Philology, 104(1), 69-82. https://doi.org/10.1086/603572

Ross, W. D. (1953). Aristotle's Metaphysics: A Revised Text with Introduction and Commentary (3rd ed.). Clarendon Press.

Segev, Mor (2017). Aristotle on Religion. Cambridge University Press. https://doi. org/10.1017/9781108231756

Silverman, Allan (2010). Contemplating Divine Mind. In David Sedley and Andrea Wilson Nightingale (Eds.), Ancient Models of Mind: Studies in Human and Divine Rationality (75-96). Cambridge University Press. https://doi.org/10.1017/CBO9780511760389.006

Thorsrud, Harald (2015). Aristotle's Dichotomous Anthropology: What Is Most Human in the Nicomachean Ethics? Apeiron, 48(3), 346-367. https://doi.org/10.1515/ apeiron-2015-0002

Walker, Matthew D. (2017). How Narrow is Aristotle's Contemplative Ideal? Philosophy and Phenomenological Research, 94(3), 558-583. https://doi.org/10.1111/phpr.12194 
Walker, Matthew D. (2018). Aristotle on the Uses of Contemplation. Cambridge University Press. https://doi.org/10.1017/9781108363341

Wedin, Michael V. (1988). Mind and Imagination in Aristotle. Yale University Press. https:// doi.org/10.2307/2185543

Whiting, Jennifer (1986). Human Nature and Intellectualism in Aristotle. Archiv für Geschichte der Philosophie, 68(1), 70-95. https://doi.org/10.1515/agph.1986.68.1.70

Whiting, Jennifer (1988). Aristotle's Function Argument: A Defense. Ancient Philosophy, 8(1), 33-48. https://doi.org/10.5840/ancientphil19888119

Wilkes, Kathleen V. (1978). The Good Man and the Good for Man in Aristotle's Ethics. Mind, 87(348), 553-571. https://doi.org/10.1093/mind/LXXXVII.4.553

Wolfson, Harry A. (1973). The Problem of the Souls of the Spheres from the Byzantine Commentaries on Aristotle through the Arabs and St. Thomas to Kepler. In H. A. Wolfson, Isadore Twersky, and George H. Williams (Eds.), Studies in the History of Philosophy and Religion (Vol. 1, 22-59). Harvard University Press. https://doi. org/10.2307/1291158 